\title{
Ground Water Assessment for Optimal Water Management in IGKV Farm, Raipur, India
}

\author{
Amit Dahate $^{1 *}$, Damini Sahu ${ }^{1}$, Prafull Katre ${ }^{1}$ and Neeraj Kumar Thakur ${ }^{1}$ \\ Department of Soil and Water Engineering \\ Indira Gandhi Krishi Vishwavidyalaya, Raipur, Pin - 492012, India \\ *Corresponding author
}

\section{Keywords \\ Ground water, Rainfall analysis, \\ Canal Irrigation, Ground water draft, Crop seasons \\ Article Info \\ Accepted: \\ 18 July 2020 \\ Available Online: \\ 10 August 2020}

\section{A B S T R A C T}

Agricultural sector is the main consumer of our available water resources and demand of water in agricultural sector is continuously increasing. This study is an attempt to prepare a plan for proper utilization of groundwater of farm of Raipur campus of Indira Gandhi Krishi Vishwavidyalaya, Raipur, Chhattisgarh. In watershed different components plays important role for recharging the groundwater such as rainfall, canal irrigation, bore well irrigation and ponds/tank irrigation. This is measured through rainfall data and electricity bills. Groundwater recharge by rainfall was 54,900 $\mathrm{m}^{3}$, from canal was $60,205.21 \mathrm{~m}^{3}$, from bore wells $218.56 \mathrm{~m}^{3}$ and from Tanks/Ponds was $8655.36 \mathrm{~m}^{3}$ respectively. Therefore, total recharge by different irrigation sources was $1,37,680.13 \mathrm{~m}^{3}$. Managing groundwater (consumptive use) in the study area means to reducing the groundwater extraction, suggested three Lift Irrigation Schemes (LIS-1, LIS-2 and LIS3) are proposed at appropriate location at the downstream of Bharri Dam at Chhokranala.

\section{Introduction}

The average annual rainfall in the country is $1194 \mathrm{~mm}$ which, if considered. India is a water harnessed country where more than 50 $\%$ of agriculture depends on rainfall, but for most parts of India, the raining period is restricted to only four months of monsoon. The country accommodates more than $17 \%$ off world's population, with $4 \%$ water resources and $2.5 \%$ land resources of the world. Agriculture is the highest water consuming sector to meet the desired agriculture production. Due to over exploitation of groundwater availability of fresh water is decreasing rapidly. In present scenario due to continue increasing demand of water in agriculture and other sectors it is difficult to suddenly identify additional resources of water so the optimal use of available water is essential. 
In a geographical area of 328 Mha, the overall volume is approximately 400 Mham. From this, only 67 Mham from surface water and 26.5 Mham of groundwater can be used in India. Indira Gandhi Krishi Vishwavidyalaya, Raipur is the state-wide leading institution in agricultural research and advanced field technology demonstrations. Increasing water efficiency is an important factor in enhancing water management for sustainable farming, food security and the functioning of a balanced ecosystem. There is also an urgent need to increase the limited resources of groundwater by taking appropriate measures, including effective management intervention. Although these problems and the related advantages of a strategically designed strategy are well known and the subject of numerous studies published on the topic of groundwater management.

\section{Material and Methods}

\section{Study area}

Area of IGKV is 200 ha which comes under Sub-tropical Climate and my study area under in IGKV farm $81^{\circ} 43^{\prime} 11^{\prime \prime}$ to $81^{\circ} 42^{\prime} 38^{\prime \prime} \mathrm{E}$ longitude $21^{\circ} 14^{\prime} 08^{\prime \prime}$ to $21^{\circ} 14^{\prime} 05^{\prime \prime} \mathrm{N}$ Latitude. Active slope of the study area is towards west to south-west. Location map of the study area is shown in Fig. 1. Main source of surface water is the water carried by the diversion canal (Tar) from the Bharri dam, constructed at the upper part of the study area on the rivulet called Chhokranala. The area of the Bharri dam is 3.78 ha. The total length of Diversion canal in study area is $793 \mathrm{~m}$ which is used for irrigation cum drainage purpose. Seven other drains exist in the study area acts mainly as drainage channels and occasionally as irrigation channel.

\section{Groundwater assessment}

Groundwater is a critical source of irrigation. In any groundwater survey importance of data collection their analysis, measurements and some of the simulation methods means the system approach should always be performed. Assessment of groundwater resources of an area yields knowledge necessary for their informed management and governance. Ground Water Estimation Committee's 1997 (revised 2015) report was considered as a base for these assessments.

\section{Groundwater recharge by infiltration method}

The ground water extraction estimation included in the computation through rainfall recharge using water level fluctuation approach is often subject to uncertainties. Therefore, it is recommended to compare the rainfall recharge obtained from water level fluctuation approach with that estimated using rainfall infiltration factor method.

Recharge from rainfall is estimated by using the following relationship -

$$
\mathrm{R}_{\mathrm{rf}}=\frac{\mathrm{RFIF \times A \times (R-a)}}{1000}
$$

Where,

$\mathrm{R}_{\mathrm{rf}}=$ Rainfall recharge in ha- $\mathrm{m}, \mathrm{RFIF}=$ Rainfall Infiltration Factor, $\mathrm{A}=$ Area in Hectares, $\mathrm{R}=$ Normal annual rainfall in $\mathrm{mm}$, $\mathrm{a}=$ Minimum threshold value above which rainfall induces ground water recharge in $\mathrm{mm}$. (Source: GEC 2015, pp 50).

\section{Ground water recharge through other resources}

Groundwater also recharge from various watershed component which are used for water storage or irrigation purposes. In this study we are calculating groundwater recharge from some of the resources such as canal, tubewells, ponds and lakes. 


\section{Groundwater recharge through canal}

Groundwater recharge due to canal seepage is estimated by following formula:

$$
\mathrm{R}_{\mathrm{c}}=\mathrm{WA} \times \mathrm{SF} \times \text { Days }
$$

Where,

$\mathrm{R}_{\mathrm{C}}=$ Recharge Due to Canals, WA=Wetted Area, $\mathrm{SF}=$ Seepage Factor

(Shown in Table 1), Days= Number of Canal Running Days.

\section{Wetted perimeter}

For calculation of groundwater recharge by canal we required wetted area of canal so we had calculated perimeter of canal, which are shown in Table 2.

\section{Groundwater recharge through Bore well irrigation}

Groundwater recharge due to surface water irrigation seepage is estimated by following formula:

$$
\mathrm{R}_{\mathrm{GWI}}=\mathrm{GD}_{1} \times \mathrm{RFF}
$$

Where,

$\mathrm{R}_{\mathrm{GWI}}=$ Recharge due to applied groundwater irrigation, $\mathrm{GD}_{1}=$ Groundwater Draft, $\mathrm{RFF}=$ Return Flow Factor (Shown in Table 3).

\section{Groundwater recharge by tanks or ponds}

Recharge due to Tanks \& Ponds is estimated based on the following formula:

$\mathrm{R}_{\mathrm{TP}}=\mathrm{AWSA}^{\times} \mathrm{N}^{\times}{ }_{\mathrm{RF}}$

Where:

$\mathrm{R}_{\mathrm{TP}}=$ Recharge due to Tanks \& Ponds, AWSA $=$ Average Water Spread area, $\mathrm{N}=$ Number of days Water is available in the Tank/Pond, RF= Recharge Factor

\section{Lift irrigation schemes (LIS)}

Two Lift irrigation schemes (LIS-1 and LIS2), lifting water from ponding behind the check dam near fisheries tank of $\mathrm{KVK}$, Raipur and irrigate area of KVK Raipur.

One Lift irrigation schemes (LIS-3), lifting water from ponding behind check dam on culvert of Airport road near horticulture farm (at sediment observation post) Horticulture farm.

\section{Result and Discussion}

\section{Groundwater assessment}

Groundwater recharge was calculated by rainfall infiltration method since data required for water level fluctuation method is not sufficient. Groundwater recharges by other watershed component were also calculated, which plays an important role in groundwater contribution.

\section{Groundwater recharge by Rainfall Infiltration method $\left(\mathbf{R}_{\mathrm{rf}}\right)$}

On the basis of analysis of annual rainfall data of previous 30 to 50 year, normal annual rainfall (shown in graph 1) of the study area is found to be $1251.44 \mathrm{~mm}$ and minimum threshold value was taken as $125.144 \mathrm{~mm}$, $10 \%$ of the normal annual rainfall. So recharge by rainfall infiltration method is worked out as $68,601 \mathrm{~m}^{3}$

\section{Groundwater recharge by other sources of watershed}

Groundwater recharge by watershed sources such as recharge from canal, recharge from bore well irrigation and recharge from Tanks/Ponds are separately calculated and shown below: 


\section{Groundwater recharge through canal $\left(R_{c}\right)$}

In our study area canal is regulated frequently in Kharif season during dry spells and occasionally in Rabi season for come up irrigation. Total length of canal as measured is $793 \mathrm{~m}$. Perimeter of canal calculated on the basis of dimensions of it measured at every 60 $\mathrm{m}$ distance.

Graph 2 shows perimeter at different sections of the diversion canal. Average wetted area of canal is worked out as $2796.99 \mathrm{~m}^{2}$. The canal is operated for approximately 123 days. So groundwater recharge through canal is worked out as $60,205.21 \mathrm{~m}^{3}$.

\section{Groundwater recharge by Bore well irrigation $\left(\mathbf{R}_{\mathrm{GW1}}\right)$}

For arriving at Groundwater draft indirectly, we had arrived on number of pumping hours in a year from each bore well in the study area. For this total power consumed by the submersible pump of that bore well was calculated based on meter reading for that pump for last 12 months mentioned in the electricity bill. Average discharge of that pump was measured and total draft was worked out by multiplying average discharge by pumping hours. Total annual draft from bore well is calculated. Return flow factor (which is a constant term and used for Kharif and Rabi season separately) values are suggested by GEC report that is already mention. So the groundwater recharge by groundwater irrigation is $218.56 \mathrm{~m}^{3}$.

\section{Pump power consumption}

In study area we collected power consumption of pumps for last 12 months and plot a graph between power consumption and months (Graph 3). First peak of power consumption is found in July month (8238 $\mathrm{kw}-\mathrm{hr}$ ), which is the field preparation time for transplanted paddy crop requiring lot of water for pudling operation. Second peak of power consumption is observed in the month of October ( $9592 \mathrm{kw}-\mathrm{hr}$ ), which is the time of withdrawal of monsoon, requiring more ground water withdrawal at reproductive phase of Paddy crop.

\section{Groundwater recharge by Tanks/Ponds $\left(\mathbf{R}_{\mathrm{TP}}\right)$}

In study area 3 ponds and 1 reservoir are situated. Three Ponds are used mainly for water storage and fish production purpose and one reservoir/dam was used mainly for storage and irrigation purpose \& other one is mainly used for water storage. Total water spread area of these water bodies is 5.60 ha and water stand for approximately 184 days. Groundwater recharge thus calculated by Tanks/Ponds is $8655.36 \mathrm{~m}^{3}$.

\section{Total groundwater recharge}

Total Groundwater recharge in the study area is the sum of recharge due to rainfall infiltration method and groundwater recharge by different watershed components such as recharge by canals bore wells, and ponds or tanks which are situated in study area.

$$
\begin{aligned}
& \mathrm{R}_{\text {Total }}=\mathrm{R}_{\mathrm{rf}}+\mathrm{R}_{\mathrm{c}}+\mathrm{R}_{\mathrm{GW} 1}+\mathrm{R}_{\mathrm{TP}} \\
& \mathrm{R}_{\text {Total }}=1,37,680.13 \mathrm{~m}^{3}
\end{aligned}
$$

\section{Optimal water management for Groundwater}

For saving of groundwater require minimum utilization of groundwater when surface water flows are available. It was observed that in the study area sufficient surface flows are available in Chhokranala from the month of July to January. Present study already suggested ways to optimally use these flows during Dry spell of Kharif season and crop 
establishment period of Rabi season by diverting them through diversion canal. Further it is observed that non command of diversion canal depends totally on ground water extracted from Bore wells during dry spells in Kharif season and crop establishment period of Rabi crop. Further it is observed that in the downstream of Bharri dam, sufficient surface flows are available.

Table.1 Norms for recharge due to seepage from canals as recommended by GEC 2015

(Anonymous 2017)

\begin{tabular}{|l|c|c|c|}
\hline \multirow{2}{*}{ Formation } & \multicolumn{3}{|c|}{$\begin{array}{c}\text { Canal Seepage factor ham/day/million square } \\
\text { meters of wetted area }\end{array}$} \\
\cline { 2 - 4 } & Recommendation & Minimum & Maximum \\
\hline $\begin{array}{l}\text { Unlined canals in normal } \\
\text { soils with some clay } \\
\text { content along with sand }\end{array}$ & 17.5 & 15 & 20 \\
\hline $\begin{array}{l}\text { Unlined canals in sandy } \\
\text { soil with some silt content }\end{array}$ & 27.5 & 25 & 30 \\
\hline $\begin{array}{l}\text { Lined canals in normal } \\
\text { soils with some clay } \\
\text { content along with sand }\end{array}$ & 3.5 & 3 & 4 \\
\hline $\begin{array}{l}\text { Lined canals in sandy soil } \\
\text { with some silt content }\end{array}$ & 5.5 & 5 & 6 \\
\hline $\begin{array}{l}\text { All canals in hard rock } \\
\text { area }\end{array}$ & 3.5 & 3 & 4 \\
\hline
\end{tabular}

Table.2 Perimeter of diversion drain (Tar)

\begin{tabular}{|l|c|c|}
\hline S.No. & Distance & Perimeters \\
\hline $\mathbf{1 .}$ & 60 & 7.048 \\
\hline $\mathbf{2 .}$ & 120 & 5.113 \\
\hline $\mathbf{3 .}$ & 180 & 4.093 \\
\hline $\mathbf{4 .}$ & 240 & 3.321 \\
\hline $\mathbf{5 .}$ & 300 & 3.349 \\
\hline $\mathbf{6 .}$ & 360 & 3.391 \\
\hline $\mathbf{7 .}$ & 420 & 2.606 \\
\hline $\mathbf{8 .}$ & 480 & 2.630 \\
\hline $\mathbf{9 .}$ & 540 & 2.907 \\
\hline $\mathbf{1 0 .}$ & 600 & 3.162 \\
\hline $\mathbf{1 1 .}$ & 660 & 2.862 \\
\hline $\mathbf{1 2 .}$ & 720 & 2.744 \\
\hline $\mathbf{1 3 .}$ & 780 & 2.622 \\
\hline Average perimeter & & 3.527 \\
\hline
\end{tabular}


Table.3 Norms for return flow from irrigation as recommended by GEC 2015 (Anonymous 2017)

\begin{tabular}{|l|l|l|l|l|}
\hline Irrigation source & Crops & \multicolumn{3}{|c|}{ Water table below ground level } \\
\cline { 3 - 5 } & & $<10 \mathrm{~m}$ & $10-25 \mathrm{~m}$ & $>25 \mathrm{~m}$ \\
\hline Ground water & Non-paddy & 25 & 15 & 5 \\
\hline Surface water & Non-paddy & 30 & 20 & 10 \\
\hline Ground water & Paddy & 45 & 35 & 20 \\
\hline Surface water & Paddy & 50 & 40 & 25 \\
\hline
\end{tabular}

Fig.1 Location map of study area

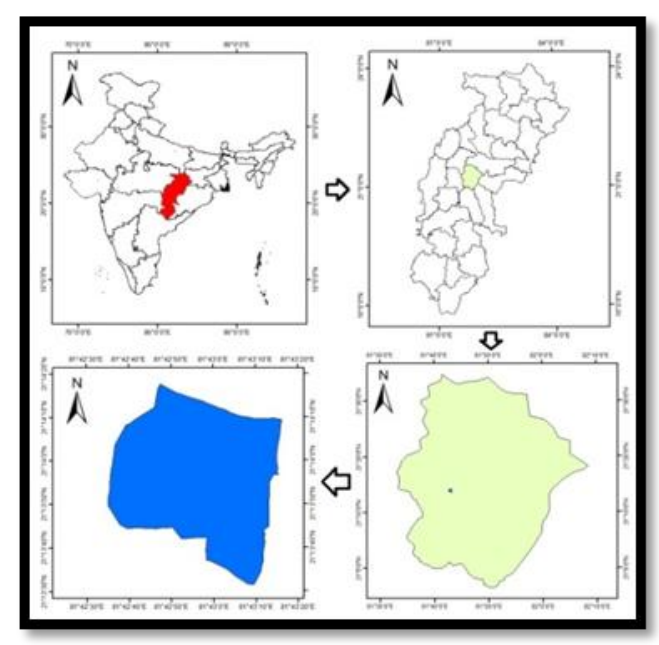

Fig.2 Proposed lift irrigation schemes

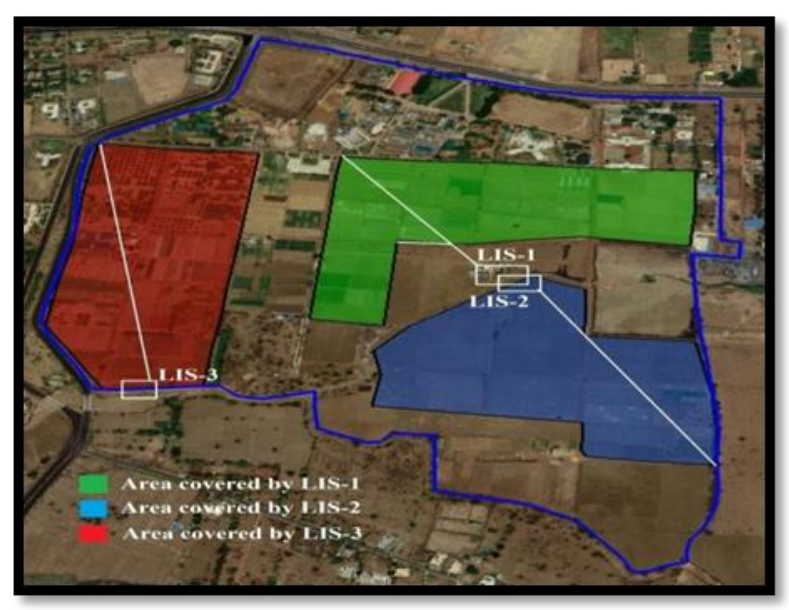


Graph.1 Normal annual rainfall of last 30 years

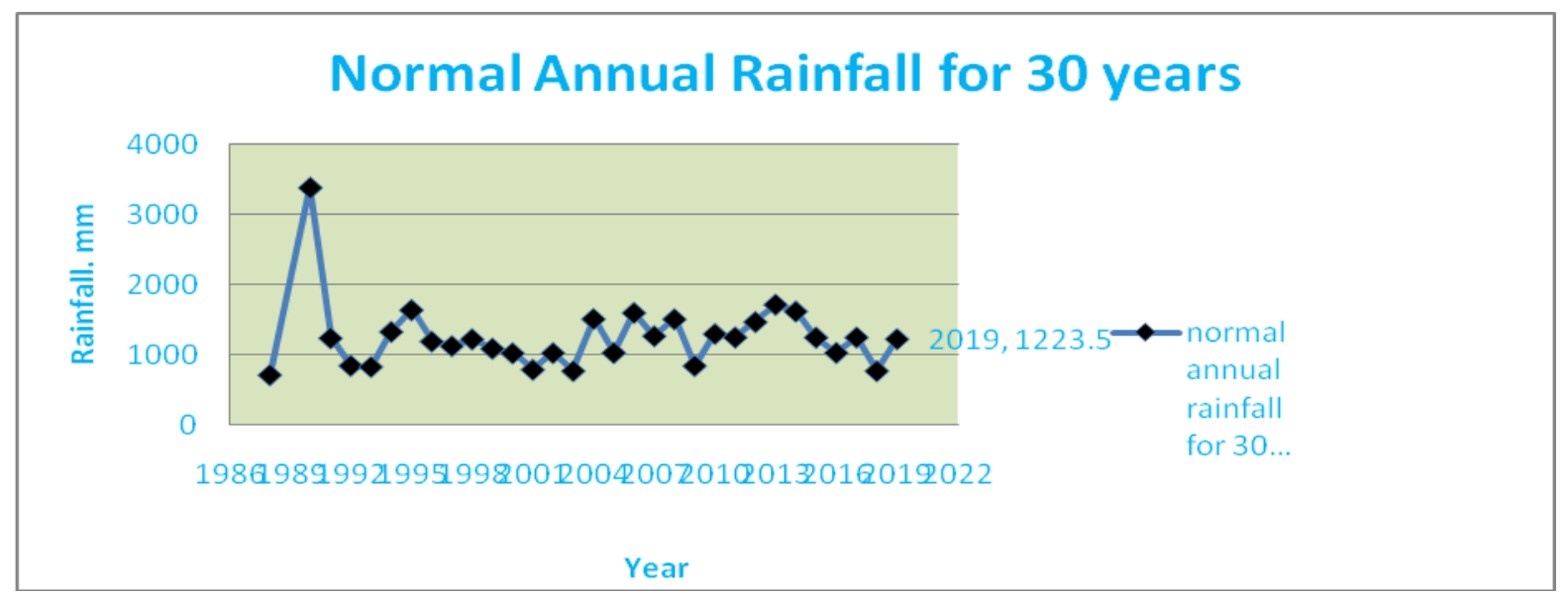

Graph.2 Perimeter of diversion canal

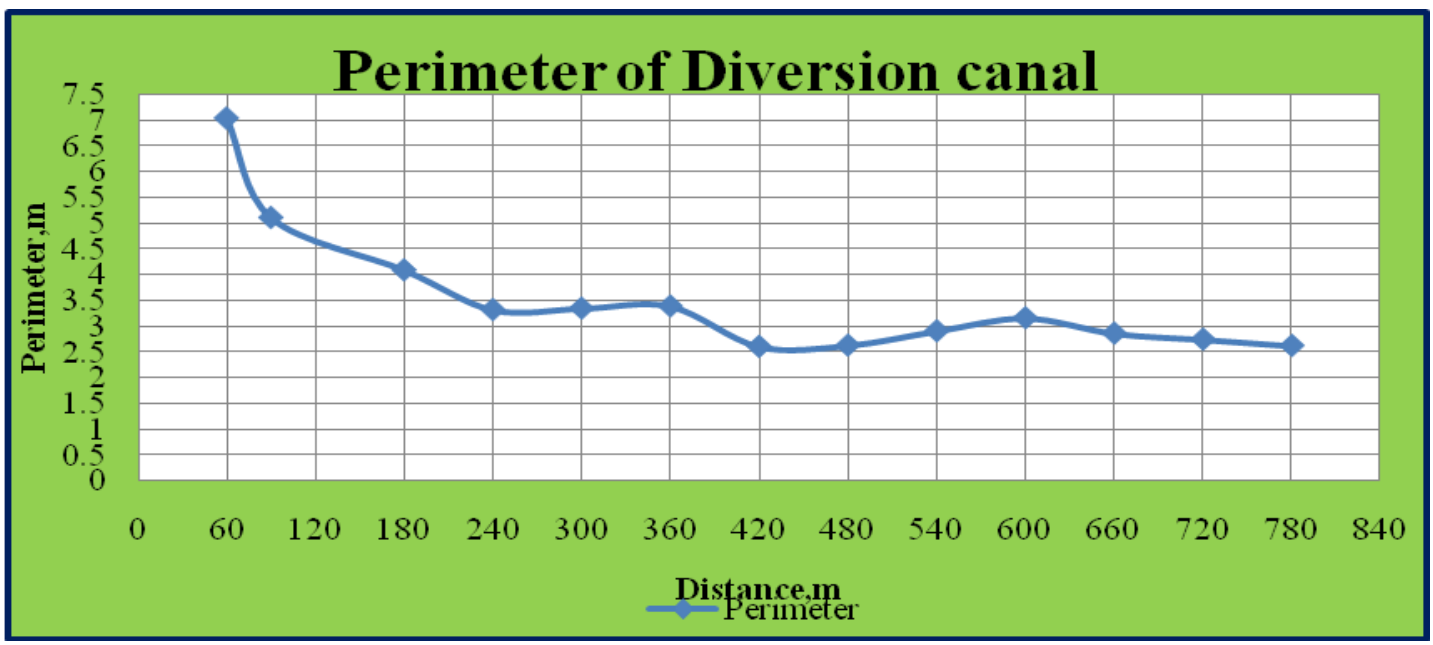

Graph.3 Month wise power consumption by pumps

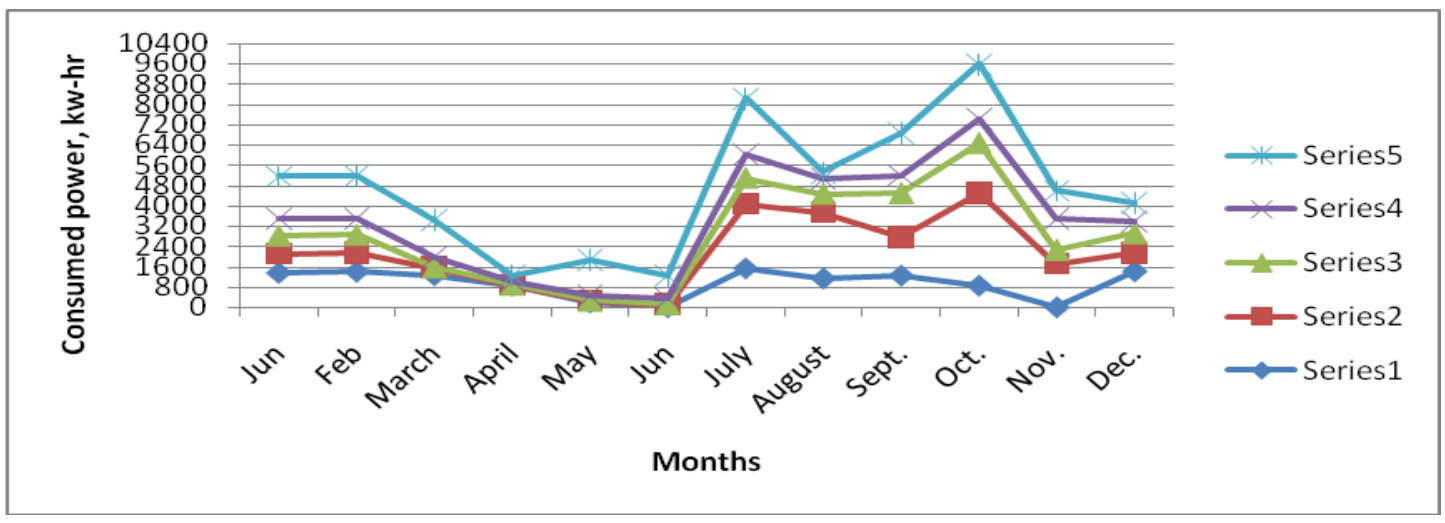


It is therefore proposed to further utilise these available surface flows by planning three lift irrigation schemes (LIS). Two lift irrigation schemes (LIS-1 and LIS- 2) are proposed to lift water from the ponding behind the check dam near fisheries tank of KVK, Raipur, One lift irrigation schemes (LIS-3) proposed to lift water from ponding behind check dam on culvert of Airport road near horticulture farm (at sediment observation post) shown in fig. 2 . Those are the proposed lift irrigation schemes which help to utilize more surface water rather the groundwater and also useful for recharging the groundwater.

\section{References}

Anonymous (2017) Report of the ground water resource estimation committee, New Delhi, pp. 8-71.

Anonymous (2019) Kurukshetra a journal on rural development. Govt. Of India, New Delhi, pp 45.

Jasrotia A.S. and Kumar A. (2014) Estimation of replenishable groundwater resources and their status of utilization in Jammu Himalaya, J\&K, India. Publication of European Water, 48: 17-27.

Katre P.K. (2016) Optimal Conjunctive Use Plan of Surface and Ground water for
Chhattisgarh Plains. S.V. College of Agricultural Engineering and Technology, \& RS, Faculty of Agricultural Engineering, IGKV, Raipur.

Lihong Yang, Yongqiang Qi, Chunmiao Zheng, Charles B. Andrews, Shenghua Yue, Sijie Lin, Yu Li, Chengjian Wang, Yaqin $\mathrm{Xu}$ and Haitao Li (2018) A Modified Water-Table Fluctuation Method to Characterize Regional Groundwater Discharge. Water, 10:503.

Pathak Sudhakar, Saxena Abhishek (2017) Conjunctive use and management of surface and groundwater resources in irrigation sector, International Journal of Scientific and Innovative Research, 5(1): 82-87.

Stasko Stanisław, Tarka Robert, Olichwer Tomasz (2012) Groundwater recharge evaluation based on the infiltration method, Research gate, pp 189.

Varni Marcelo, Comas Rocío, Weinzettel Pablo, Dietrich Sebastián (2013) Application of the water table fluctuation method to characterize groundwater recharge in the Pampa plain, Argentina, Journal of Hydrological Science, 58 (7).

\section{How to cite this article:}

Amit Dahate, Damini Sahu, Prafull Katre and Neeraj Kumar Thakur. 2020. Ground Water Assessment for Optimal Water Management in IGKV Farm, Raipur, India. Int.J.Curr.Microbiol.App.Sci. 9(08): 1528-1535. doi: https://doi.org/10.20546/ijcmas.2020.908.177 